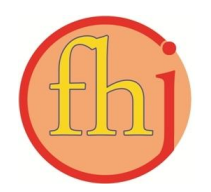

Faletehan Health Journal, 6 (3) (2019) 91-98

www. journal.Ippm-stikesfa.ac.id/ojs/index.php/FHJ

ISSN 2088-673X | e-ISSN 2597-8667

\title{
Perbandingan Metode Kolostrum dan Metode Terbuka Terhadap Lama Pelepasan Tali Pusat pada Bayi Baru Lahir
}

\author{
Ruri Yuni Astari ${ }^{*}$, Dinda Nurazizah $^{1}$ \\ 1Prodi D III Kebidanan STIKes YPIB M ajalengka \\ *Corresponding Author: ruri_ya@yahoo.co.id
}

\begin{abstract}
Abstrak
Perawatan tali pusat adalah pengobatan dan pengikatan tali pusat yang menyebabkan pemisahan fisik terakhir antara ibu bayi, kemudian tali pusat dirawat dalam keadaan steril, bersih, kering, puput dan terhindar dari infeksi tali pusat. Metode perawatan tali pusat yang efektif mempercepat pelepasan tali pusat dan mengurangi kejadian infeksi. Penelitian ini bertujuan untuk membandingkan lama pelepasan tali pusat dengan metode kolostrum dan metode terbuka dalam proses pelepasan tali pusat bayi baru lahir. Jenis penelitian menggunakan experiment static group comparism. Sampel penelitian ini adalah bayi baru lahir sebanyak 30 responden dibagi menjadi 2 kelompok, 15 responden kelompok intervensi dan 15 responden kelompok kontrol. Hasil penelitian menunjukkan bahwa lama pelepasan tali pusat dengan metode kolostrum adalah $<5$ hari (kategori cepat) dan tidak ada yang $>7$ hari (kategori lambat). Lama pelepasan tali pusat dengan metode terbuka menunjukkan tali pusat lepas $\measuredangle$ hari (kategori cepat) dan tali pusat lepas $>7$ hari (kategori lambat). Hasil uji statistik menunjukkan bahwa lama pelepasan tali pusat bayi baru lahir dengan metode kolostrum sekitar 4 hari 9 jam lebih cepat dibandingkan metode terbuka $(\rho=0,022)$. Saran dalam penelitian ini adalah petugas kesehatan perlu mendapatkan informasi tentang perawatan tali pusat dengan metode kolostrum sehingga dapat diterapkan pada bayi baru lahir.
\end{abstract}

Kata Kunci: Bayi Baru Lahir, M etode Kolostrum, M etode Terbuka, Tali Pusat

\begin{abstract}
Umbilical cord care is the treatment and binding of the umbilical cord which causes the last physical separation between the mother of the baby, then the umbilical cord is treated in a sterile, clean, dry and protected from umbilical cord infection. The umbilical cord treatment method effectively speeds up the release of the umbilical cord and reduces the incidence of infection. This study aims to compare the length of umbilical cord release with the colostrum method and the open method in the process of releasing newborn umbilical cord. This type of research uses the experiment of static group comparism. The sample of this study was 30 newborns divided into 2 groups, 15 respondents in the intervention group and 15 respondents in the control group. The results showed that the timing of umbilical cord separation with the colostrum method was $<5$ days (fast category) and none had $>7$ days (slow category). M eanwhile, the timing of umbilical cord separation with the open method was $<5$ days (fast category) and the cord was fallen off $>7$ days (slow category). The results show that the length of the umbilical cord release for newborns with the colostrum method is about 4 days 9 hours faster than the open method $(\rho=0.022)$. Health workers need to get information about cord care with the colostrum method so that it can be applied to newborns.
\end{abstract}

Keywords: Newborns, Colostrum M ethod, Open M ethod, Umbilical Cord Separation 
Faletehan Health Journal, 6 (3) (2019) 91-98

www. journal.Ippm-stikesfa.ac.id/ojs/index.php/FHJ

ISSN 2088-673X | e- ISSN 2597-8667

\section{Pendahuluan}

Angka Kematian Bayi (AKB) merupakan salah satu indikator pembangunan kesehatan dalam Rencana Pembangunan Jangka Menengah Nasional (RPJMN) 2015-2019 dan Sustainable Development Goals (SDGs). Survey Penduduk Antar Sensus (SUPAS) pada tahun 2015 melaporkan AKB sebesar 22,23/1000 kelahiran hidup dan pada tahun 2016 jumlah kematian bayi sebesar 32.007 jiwa dengan penyebab kematian bayi baru lahir di Indonesia adalah asfiksia, Berat Bayi Lahir Rendah (BBLR), tetanus neonatorium $(10 \%)$, masalah pemberian makan (10\%), infeksi $(6,7 \%)$, gangguan hematologik $(5 \%)$ dan lainlainnya (27\%) (WHO, 2015).

Angka Kematian Bayi (AKB) di Indonesia tahun 2015 sebesar 22,23 per 1.000 kelahiran hidup dan Angka Kematian Balita (AKABA) sebesar 26,29 per 1.000 kelahiran hidup (Kementerian Kesehatan RI., 2017). AKB di Propinsi Jawa Barat pada tahun 2015 mencapai 30 per 1.000 kelahiran hidup dan AKBA mencapai 36 per 1.000 kelahiran hidup (Dinas Kesehatan Propinsi Jawa Barat, 2017). Sementara di Kabupaten Majalengka jumlah kematian bayi pada tahun 2016 sebanyak 136 kasus. Kematian neonatal 0-28 hari ada 111 kasus penyebabnya adalah Berat Badan Lahir Rendah 46 orang $(41,44 \%)$, asfiksia 34 orang $(30,6 \%)$, sepsis 6 orang $(5,4 \%)$, icterus 1 orang $(0,9 \%)$, kelainan kongenital 11 orang $(9,9 \%)$ dan penyebab lainnya 13 orang $(11,7 \%)$, sedangkan kematian bayi 29 hari-11 bulan sebanyak 25 kasus penyebabnya adalah penyakit pneumonia 5 orang (20\%), diare 4 orang (16\%), kelainan syaraf 1 orang (4\%) dan lain-lain 15 orang (60\%) (Dinas Kesehatan Kabupaten Majalengka, 2017).

Perawatan tali pusat merupakan salah satu upaya untuk mencegah terjadinya infeksi neonatal. Tali pusat dapat merupakan pintu masuk bagi infeksi ke tubuh bayi, maka diperlukan tindakan perawatan tali pusat yang tepat agar bayi terhindar dari infeksi salah satunya infeksi tetanus neonatorum. Penyakit ini disebabkan spora clostridium tetani karena masuknya spora kuman tetanus ke dalam tubuh melalui tali pusat akibat perawatan atau tindakan yang tidak memenuhi syarat kebersihan. Perawatan tali pusat yang tidak baik mengakibatkan tali pusat menjadi lama lepas. Risiko bila tali pusat lama lepas adalah terjadinya infeksi tali pusat dan tetanus neonatorum (Supriyani. F dan Handayani. S, 2011). Angka kematian bayi terbanyak berada di Puskesmas Maja sebesar 7 orang, penyebabnya yaitu 5 orang diakibatkan karena BBLR, asfiksia 1 orang dan 1 orang terinfeksi tetanus neonatorum (Dinkes Kab. Majalengka., 2016).

Tali pusat merupakan saluran kehidupan bagi janin selama di dalam kandungan. Tali pusat berfungsi menyalurkan oksigen dan nutrien dari plasenta ke janin selama proses kehamilan. Paska dilahirkan tali harus dipotong dan dijepit atau diikat kuat agar pembuluh darah oklusi serta tidak terjadi perdarahan. Tali pusat dalam beberapa hari akan terlepas sendiri setelah mengalami proses nekrosis (adanya jaringan yang mati) menjadi kering pada hari ke-6 hingga ke- 8 dengan meninggalkan luka granulasi kecil (jaringan fibrosa yang terbentuk dari bekuan darah sebagai bagian dari proses penyembuhan luka, sampai matang menjadi jaringan parut) yang setelah sembuh akan membentuk umbilikus atau pusar (Hastuti, 2014 ;Withmore JM, 2010). Kondisi tali pusat yang kurang bersih dan kering bisa menyebabkan infeksi tali pusat seperti bau menyengat, kemerahan pada kulit dasar tali pusat, kemerahan yang menyebar, ke abdomen dan purulen. Pada keadaan lanjut bila tidak ditangani setelah tanda-tanda infeksi dini ditemukan, infeksi dapat menyebar kebagian dalam tubuh disepanjang vena umbilicus dan akan mengakibatkan thrombosis vena porta, abses hepar dan septikemia. Penting dilakukan perawatan tali pusat dengan rutin dan cermat, dan melaporkan sedini mungkin bila dijumpai tanda-tanda infeksi pada tali pusat (Ronald, 2011; Elsobky FAA, et al., 2017).

Perawatan tali pusat awalnya dilakukan dengan menggunakan berbagai ramuan serta bahan - bahan lain dan dilakukan oleh dukun bayi. Peningkatan kematian bayi akibat infeksi dari tali pusat menyebabkan perawatan tali pusat menjadi salah satu hal yang penting diperhatikan seperti penggunaan cairan antiseptik povidon iodine $10 \%$ atau alkohol $70 \%$. Perawatan tali pusat menggunakan antiseptik kemudian dianggap kurang baik karena mengakibatkan tali pusat basah dan lembab sehingga memperlambat putusnya tali pusat dan menimbulkan risiko infeksi (WHO, 2010). Riset Kesehatan Dasar (Riskesdas) tahun 2013 menyatakan bahwa informasi tentang cara perawatan tali pusat bayi baru lahir menurut standar Asuhan Persalinan Normal (APN) adalah 
Faletehan Health Journal, 6 (3) (2019) 91-98 www. journal.Ippm-stikesfa.ac.id/ojs/index.php/FHJ ISSN 2088-673X | e- ISSN 2597-8667

tali pusat yang telah dipotong dan diikat, tidak diberi apa-apa.

Pada hasil penelitian Fita S dan Sri H (2011) menunjukkan bahwa waktu pelepasan yang diberi perawatan ASI 2 hari 1 jam lebih cepat daripada dengan perawatan kassa kering selama 6 hari 4 jam.(Supriyani.F dan Handayani. H, 2011) Pada penelitian Insani. WN (2015), melakukan penelitian perawatan tali pusat dengan menggunakan kolostrum dan kassa kering, dengan hasil metode kolostrum 2 hari lebih cepat dibandingkan kassa kering (Insani. WN, 2015).

Kolostrum memiliki banyak manfaat, antara lain pemenuhan gizi bayi, berperan sebagai zat kekebalan tubuh, anti inflamasi, anti bakterial, anti viral, anti parasit dan anti alergi. Perawatan tali pusat dengan metode topikal ASI adalah perawatan tali pusat yang dibersihkan dan dirawat dengan cara mengoleskan kolostrum pada luka dan sekitar luka tali pusat. Cairan yang volumenya berkisar 150-300 ml/24 jam ini merupakan cairan yang pertama kali disekresi oleh kelenjar payudara, mengandung tissue debris dan residual material yang terdapat dalam alveoli dan duktus dari kelenjar payudara sebelum dan setelah masa puerperium. (Erlina HNP, 2013).

SigA di dalam kolostrum sangat berkhasiat untuk melindungi tubuh bayi terhadap infeksi. (IDAI, 2013). SigA adalah antibodi yang paling banyak diproduksi oleh tubuh melalui sistem mukosa terutama pada MALT (Mucosa Associated Lymphoid Tissues). SigA dalam kolosrum berfungsi mencegah absorpsi protein-protein asing ketika SigA bayi belum terbentuk. SigA bayi berasal dari sel-sel plasma di dalam lamina propia dan kelenjar limfe di bawah mukosa saluran pencernaan dan belum berproduksi pada umur minggu pertama kelahiran. Manfaat pemberian kolostrum kepada bayi baru lahir adalah sebagai proteksi dari infeksi yang disebabkan virus, bakteri, parasit dan antigen lainnya. Protein dalam kolostrum yang tinggi mencapai 4,1 gr\% juga berperan dalam perbaikan sel-sel yang rusak, mempercepat proses penyembuhan sehingga mampu mempercepat waktu pelepasan tali pusat (Ika S dan Ely EA, 2013).

Studi kasus yang dilakukan di wilayah Puskesmas Maja melalui wawancara dengan koordinator bidan diketahui bahwa selama ini perawatan tali pusat dilakukan dengan cara membersihkan tali pusat dengan sabun dan air, serta menjaganya agar tidak lembab, sesuai dengan referensi WHO (2010). Lama pelepasan tali pusat dengan metode tersebut rata - rata sekitar 5-7 hari. Penggunaan kolostrum sebagai topical dalam perawatan tali pusat sampai saat ini belum pernah dilakukan karena kurangnya informasi mengenai penggunaan kolostrum ini. Maka peneliti tertarik untuk mengetahui lebih lanjut tentang perbandingan Metode Kolostrum dan Metode Terbuka terhadap Lama Pelepasan Tali Pusat pada Bayi Baru Lahir di Puskesmas Maja Kabupaten Majalengka.

\section{Metode Penelitian}

Jenis penelitian ini adalah eksperimen static group comparism. Peneliti membagi dua kelompok penelitian, kelompok pertama menggunakan perawatan tali pusat dengan metode kolostrum (kelompok intervensi/ $\mathrm{O}_{1}$ ) dan kelompok kedua menggunakan perawatan tali pusat dengan metode terbuka (kelompok kontrol/ $\mathrm{O}_{2}$ ). Kelompok intervensi mendapatkan perlakuan pengolesan topical kolostrum selama perawatan tali pusat sedangkan pada kelompok kontrol perawatan menggunakan metode terbuka.

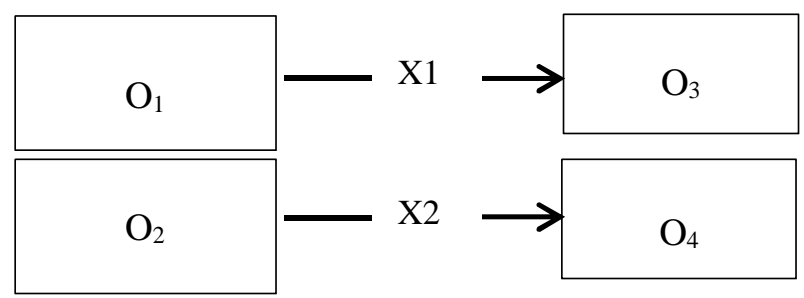

Keterangan :

O1: Kelompok intervensi sebelum dilakukan perawatan

$\mathrm{X} 1$ : tali pusat dengan kolostrum

O3: Kelompok intervensi setelah dilakukan perawatan

O2: Kelompok kontrol sebelum dilakukan perawatan

$\mathrm{X} 2$ : Perawatan tali pusat dengan metode terbuka

O4: Kelompok kontrol sebelum dilakukan perawatan

Sampel dalam penelitian ini adalah bayi baru lahir berjumlah 30 yang memenuhi kriteria penelitian yaitu:

a. Bayi Baru Lahir yang dilahirkan secara normal di Puskesmas Maja.

b. Bayi Baru Lahir dengan Berat Badan 2500 gram sampai 4000 gram. 
c. Bayi Baru Lahir yang berdomisili di Kecamatan Maja Kabupaten Majalengka.

d. Bayi dengan 6 jam postnatal sesudah bayi dimandikan.

Teknik pengambilan sampel ini menggunakan purposive sampling yaitu teknik untuk menentukan sampel penelitian dengan beberapa pertimbangan tertentu yang bertujuan agar data yang diperoleh nantinya bisa lebih representative. Analisa data menggunakan analisa univariat dengan distribusi frekuensi dan analisis bivariat dengan uji $\mathrm{t}$ independen.

\section{Hasil dan Pembahasan \\ Gambaran Lama Pelepasan Tali Pusat Bayi Baru Lahir dengan Metode Kolostrum}

Hasil analisis pada tabel 1, menunjukkan tidak ada $(0 \%)$ pelepasan tali pusat pada periode lambat dan sebanyak 33,3\% pelepasan tali pusat pada periode cepat. Perawatan kolostrum adalah perawatan tali pusat dengan menggunakan cairan kental berwarna kekuningan yang keluar sebelum ASI matur, atau ASI yang keluar pada hari ke 1 sampai hari ke 3 paska lahir. Kolostrum berfungsi untuk melindungi permukaan organ tubuh yang terpapar dengan mencegah penempelan bakteri dan virus (Wulan Nur Insani, 2015). Kolostrum mengandung protein yang sangat tinggi, berfungsi sebagai pembentuk ikatan esensial tubuh, mengatur keseimbangan cairan tubuh, memelihara netralisasi tubuh dengan bereaksi terhadap asam basa agar $\mathrm{pH}$ tubuh seimbang, membentuk antibodi serta memegang peranan penting dalam mengangkut zat gizi ke dalam jaringan. Protein yang berada dalam kolostrum dan ASI akan berikatan dengan protein dalam tali pusat sehingga membentuk reaksi imun dan terjadi proses apoptusis (nekrosis). Antioksidan dalam kolostrum juga mampu mengatasi reaksi inflamasi yang terjadi sebagai respon tubuh terhadap adanya suatu infeksi.

ASI yang dikenal sebagai emas cair adalah cairan serosa berwarna kuning tua yang mengandung banyak antibodi IgA, IgG, IgM dan memiliki efek mencegah infeksi kulit. Juga memiliki efek sebagai antibakteri, antivirus, mendukung kekebalan tubuh, meningkatkan pemulihan dan pertumbuhan muskuloskeletal juga. IgA dalam kolostrum sangat efektif melindungi bayi dari infeksi apa pun dan mencegah penyerapan protein asing.( Yulanda NA, et.al. 2015). ASI mudah tersedia dan mudah digunakan sebagai metode noninvasif untuk perawatan tali pusat. Aplikasi ASI memiliki waktu pemisahan tali pusat yang lebih pendek dibandingkan solusi antiseptik. ASI telah digunakan sebagai obat rumahan untuk penyakit ringan, seperti konjungtivitis, gigitan dan sengatan serangga, dermatitis kontak, dan luka, luka bakar, dan lecet yang terinfeksi.(Elsobky FAA. et al., 2017)

Ketika bayi lahir tali pusat bayi berwarna putih keabu-abuan, mengkilat, licin, dan segar yang dalam beberapa hari akan berubah warna menjadi kekuningan dan bentuk tali pusat sedikit menyusut berubah warna menjadi hitam keunguunguan, kisut dan mengecil pada hari ke 5-7 hari ataupun kadang pada 14 hari pertama setelah kelahiran yang kemudian akan timbul lingkaran yang berwarna kekuningan dan mengeluarkan lendir pada pangkal tali pusat kemudian tali pusat lepas dengan sendirinya dalam 1-2 minggu pertama kelahiran bayi. Kebersihan bayi merupakan suatu hal yang sangat penting sebelum melakukan perawatan tali pusat dan lebih baik dilakukan setelah bayi dimandikan yaitu sekitar 6 jam setelah bayi lahir (Puji. H, 2014). Maka dari itu, dalam perawatan tali pusat dengan metode kolostrum sangat baik untuk mencegah adanya infeksi tali pusat pada bayi baru lahir dan dapat mempercepat pelepasan tali pusat. Artinya bila tidak ada infeksi maka pelepasan tali pusat pun akan lebih cepat. Perawatan dengan menggunakan kolostrum memiliki beberapa manfaat yaitu murah, mudah, alami, hanya membutuhkan waktu sebentar, bersih, mencegah infeksi pada bayi, aman, mengurangi waktu pemisahan tali pusat dan memberikan kebutuhan psikologis antara ibu dan bayinya (Bounding Attachment) (Aghamohammadi, A.et.al. 2012).

Tabel 1. Lama Pelepasan Tali Pusat Bayi Baru Lahir Menggunakan Metode Kolostrum

\begin{tabular}{lcc}
\hline \multicolumn{1}{c}{ Kategori } & F & \% \\
\hline Cepat (<5hari) & 5 & 33.3 \\
Sedang (5-7hari) & 10 & 66.7 \\
Lambat (>7hari) & 0 & 0 \\
\hline Jumlah & $\mathbf{1 5}$ & $\mathbf{1 0 0}$ \\
\hline
\end{tabular}


Faletehan Health Journal, 6 (3) (2019) 91-98 www. journal.Ippm-stikesfa.ac.id/ojs/index.php/FHJ ISSN 2088-673X | e- ISSN 2597-8667

Menurut penelitian Fita S dan Sri Handayani, perawatan tali pusat dilakukan dengan cara dioleskan sekitar $1-2$ tetes ke pangkal tali pusat secara menyeluruh selama 2 kali sehari setelah bayi dimandikan untuk menjaga kebersihannya.(Fita $S$ dan Sri H, 2011) Menurut penelitian Ika S dan Ely Eko (2011), penggunaan kolostrum dalam perawatan tali pusat memiliki efektifitas 94,23 jam, dengan waktu tercepat yaitu 54,83 jam dan waktu terlambat yaitu 170,50 jam. Hal ini dapat dipengaruhi oleh kandungan kolostrum yang memiliki protein yang tinggi mencapai $4,1 \mathrm{gr} \%$, ini sangat berperan dalam perbaikan sel-sel yang rusak, mempercepat proses penyembuhan sehingga mampu mempercepat waktu pelepasan tali pusat (Ika S dan Ely EA. 2011). Perlunya memberikan informasi kepada ibu dan keluarga dalam melakukan perawatan tali pusat dengan metode kolostrum sehingga ibu dan keluarga dapat menerapkannya di rumah.

\section{Gambaran Lama Pelepasan Tali Pusat Bayi Baru Lahir dengan Metode Terbuka}

Hasil analisis pada tabel 2, menunjukkan sebagian kecil (20\%) pelepasan tali pusat pada periode lambat dan sebanyak $13,3 \%$ pelepasan tali pusat pada periode cepat. Setelah dilakukan wawancara kepada beberapa bidan di Puskesmas Maja, metode terbuka telah dilakukan sejak WHO memberitahukan tentang cara merawat tali pusat dengan metode terbuka pada tahun 2010, dan sampai saat ini metode ini masih digunakan. Hampir seluruh masyarakat terutama keluarga bayi yang lahir di Puskesmas Maja sudah mengetahui metode terbuka. Pada beberapa tahun ke belakang, perawatan tali pusat dengan menggunakan alkohol $70 \%$, povidon iodine, kunyit atau ramuan lainnya masih ditemukan di beberapa tempat terutama di daerah Maja, sehingga kasus kematian bayi akibat tetanus masih sering dijumpai. Meski petugas kesehatan agak kesulitan dengan penyampaian informasi tersebut, namun seiring berjalannya waktu akhirnya masyarakat mengerti akan cara perawatan tali pusat dengan menggunakan metode terbuka lebih alami dan baik bagi bayi. Masyarakat pun sudah mengerti bahwa cara untuk mempercepat pelepasan tali pusat dapat dilakukan tanpa menggunakan alkohol 70\%, povidon iodine, kunyit atau ramuan.

Pelepasan tali pusat dengan bantuan udara menurut Dewi (2010), setelah tali pusat dipotong terjadi kolonisasi pada tali pusat yang dimulai dalam beberapa jam setelah lahir akibat dari organisme non patogenik yang berasal dari ibu dan masuk ke bayi melalui kontak dari kulit ke kulit (Dewi dkk, 2011). Bakteri yang berbahaya dapat disebarkan melalui higiene yang buruk, teknik cuci tangan yang tidak baik dan khususnya infeksi silang dari pekerja kesehatan (Lumsden, 2012). Dalam tali pusat yang berasal dari body stalk terdapat jaringan lembek (jelly whar ton). Body stalk atau tangkai tubuh adalah daerah tempat tertanamnya embrio ke dalam endometrium induk. Daerah ini semula berada di atas amnion. Ketika amnion membesar, embrio bergeser dari tangkai tubuh, sehingga berada di posterior (kauda). Tangkai tubuh akan mengalami pemanjangan dan perampingan menjadi tali pusat (korda umbilikalis).

Jeli wharton merupakan zat yang berkonsistensi lengket yang mengelilingi pembuluh darah pada funiculus umbilicalis. Jeli Wharton merupakan subtansi seperti jeli, juga berasal dari mesoderm seperti halnya pembuluh darah. Jeli ini melindungi pembuluh darah tersebut terhadap kompresi, sehingga pemberian makanan yang kontinyu untuk janin dapat di jamin. Selain itu juga dapat membantu mencegah penekukan tali pusat. Jeli wharton ini akan mengembang jika terkena udara dan kadang terkumpul sebagai gumpalan kecil dan membentuk simpul palsu di dalam funiculus umbilicalis. Jumlah jeli inilah yang menyebabkan funiculus umbilicalis menjadi tebal atau tipis. Jeli Wharton banyak mengandung air, maka setelah bayi lahir, tali pusat mudah kering dan lekas terlepas dari pusar bayi (Cunningham et al., 2006). Pada saat tali pusat terpotong maka suplai darah dari ibu terhenti. Tali pusat yang masih menempel pada pusat bayi lama kelamaan akan kering dan terlepas. Pengeringan dan pemisahan tali pusat sangat dipengaruhi oleh Jelly Wharton atau aliran udara yang mengenainya. Jaringan pada sisa tali pusat dapat dijadikan tempat koloni oleh bakteri terutama jika dibiarkan lembab dan kotor.

Tabel 2. Lama Pelepasan Tali Pusat Bayi Baru Lahir dengan Metode Terbuka

\begin{tabular}{lcc}
\hline \multicolumn{1}{c}{ Kategori } & F & \% \\
\hline Cepat (<5hari) & 2 & 13.3 \\
Sedang (5-7hari) & 10 & 66.7 \\
Lambat (>7hari) & 3 & 20 \\
\hline Jumlah & $\mathbf{1 5}$ & $\mathbf{1 0 0}$ \\
\hline
\end{tabular}


Jeli wharton bila terkena suhu dingin atau udara di luar tubuh ibu, akan berubah strukturnya dan secara fisiologis berubah fungsi menjadi padat dan mengeklem tali pusat secara otomatis dalam waktu 5 sampai 30 menit setelah bayi dilahirkan. Dengan demikian, pengekleman tali pusat sebenarnya tidak diperlukan sama sekali (Aprilia, 2014). Dengan terjadinya pengekleman oleh Jeli Wharton pada tali pusat menyebabkan aliran darah pada pembuluh darah didalam sisa tali pusat terhambat atau bahkan tidak mengalir lagi. Tali pusat tidak mendapat aliran darah sehingga menjadi kering dan layu yang kemudian sisa tali pusat akan terlepas. Paparan udara menyebabkan kandungan air pada Jeli Wharton dan pembuluh darah berkurang atau bahkan menghilang. Hilangnya air dari Jeli Wharton menyebabkan mumifikasi tali pusat segera setelah bayi lahir (Cunningham et al., 2006). Mumifikasi tali pusat yakni perubahan warna putih tali pusat atau bahkan warna putih tali pusat menghilang dan berubah menjadi kuning kecoklatan, mengering atau kehitaman kering, dan kaku. Setelah terjadinya mumifikasi, tali pusat akan mengering dan mengalami perubahan morfologi sehingga cepat terlepas dari umbilikus bayi. Wharton Jelly terdiri dari mucopolysaccharides (lemak), sel darah putih, dan sel batang (Aprilia, 2014).

Hunt dalam Amrullah (2015) memaparkan bahwa salah satu faktor yang memengaruhi proses penyembuhan luka ialah oksigenasi jaringan. Proses ini sangat membutuhkan oksigenasi yang cukup. Semakin baik oksigenasi yang terjadi maka proses penyembuhan luka akan semakin cepat. Kadar oksigen di jaringan penting untuk pembentukan sel-sel baru penyembuh luka. Luka yang terbuka atau dibiarkan terkena udara, lapisan permukaannya akan cepat mengering. Oksigen memegang peranan penting didalam pembentukan kolagen, kapiler-kapiler baru, perbaikan epitel, dan pengendalian infeksi. Oleh karena itu, penutup atau pembalut tali pusat harus dipilih dengan tepat agar pertukaran gas dan udara tetap lancar. Namun, sebaiknya tali pusat tetap dibiarkan terbuka agar tali pusat terkena udara dengan leluasa sehingga proses pelepasan tali pusat berlangsung cepat (Amrullah, 2015).

Hasil penelitian menunjukkan bahwa perawatan tali pusat kolostrum dan perawatan terbuka tidak menyebabkan infeksi tali pusat dengan persentase sebesar $100 \%$. Peneliti melakukan follow up setiap harinya untuk menanyakan tanda-tanda infeksi tali pusat seperti adanya nanah, perdarahan, peningkatan suhu bayi, bau yang tidak sedap, tanda kemerahan disekitar pangkal tali pusat dan tanda-tanda infeksi lainnya. Hasil penelitian menunjukkan bahwa tidak ditemukan tanda-tanda infeksi tali pusat yang terjadi pada kedua kelompok. Tanda-tanda infeksi bayi terlihat gelisah dan rewel, terlihat adanya tanda kemerahan disekitar pangkal tali pusat dan perut bayi, daerah sekitar tali pusat tercium aroma bau dan mengeluarkan nanah, dan suhu bayi meningkat. Hasil ini sejalan dengan penelitian Gloshan dan Husein (2013) menunjukkan bahwa kelompok yang menggunakan metode kolostrum lebih cepat pelepasan tali pusat dibandingkan metode terbuka dan alkohol 70\% (Mohammad Golshan, 2013). Penelitian serupa Pujar, DF (2013) menunjukkan bahwa pelepasan tali pusat dengan metode kolostrum lebih cepat dibandingkan yang tidak dilakukan perlakuan dengan kolostrum (Pujar. DF, 2013).

\section{Perbandingan Lama Pelepasan Tali Pusat dengan menggunakan Metode Kolostrum dan Metode Terbuka pada Bayi Baru Lahir}

Hasil penelitian pada tabel 3, menunjukkan rata - rata lama pelepasan tali pusat pada bayi baru lahir adalah antara 4,93 atau sekitar 4,9 hari pada metode kolostrum dan 5,8 hari pada metode terbuka. Ini menunjukkan terdapat perbedaan lama pelepasan tali pusat antara metode kolostrum dan metode terbuka dengan selisih waktu 0,87 hari atau 20,88 jam. Hasil penelitian ini menunjukkan bahwa hubungan yang signifikan $(p v=0,002)$ antara kedua metode perawatan tali pusat dengan lama pelepasan tali pusat.

Tabel 3. Perbandingan Lama Pelepasan Tali Pusat dengan Metode Kolostrum dan Metode Terbuka

\begin{tabular}{cccccc}
\hline Jenis Perawatan Tali Pusat & N & Mean & $\boldsymbol{P}_{\text {value }}$ & $\begin{array}{c}\text { Std. } \\
\text { Deviation }\end{array}$ & $\begin{array}{c}\text { Std. Error } \\
\text { Mean }\end{array}$ \\
\hline Kolostrum & 15 & 4,93 & \multirow{2}{*}{0,022} & 1,280 & 0,330 \\
Terbuka & 15 & 5,80 & & 1,424 & 0,368 \\
\hline
\end{tabular}


Faletehan Health Journal, 6 (3) (2019) 91-98 www. journal.Ippm-stikesfa.ac.id/ojs/index.php/FHJ ISSN 2088-673X | e- ISSN 2597-8667

Suplay darah dari ibu akan terlepas saat pemotongan tali pusat. Setelah dilakukan pemotongan dan pengikatan hal yang perlu dilakukan yaitu merawat tali pusat. Adapun tujuan perawatan tali pusat yaitu untuk menjaga agar tali pusat tetap kering dan terhindar terjadinya infeksi (Vivian, 2008). Perawatan tali pusat diperlukan untuk mencegah tali pusat menjadi media perkembangbiakan mikroorganisme patogen. Perawatan tali pusat yang baik dan benar akan menimbulkan dampak positif yaitu tali pusat akan pupus pada hari ke-5 dan hari ke-7 tanpa ada komplikasi, sedangkan dampak negatif dari perawatan tali pusat yang tidak benar adalah bayi akan mengalami penyakit tetanus neonatorum dan dapat mengakibatkan kematian (JNPK, 2011).

Mekanisme pelepasan tali pusat dengan perawatan terbuka dimulai dari pengikatan dan pemotongan tali pusat yang mengakibatkan tali pusat tidak mendapat suplai darah (asupan makanan). Denyutan (pulsasi) akan berhenti karena suhu luar menyebabkan kontraksi, kemudian pembuluh darah kehilangan air secara mendadak. Tali pusat tidak mendapat aliran darah sehingga menjadi kering dan layu. Pengeringan dan pelepasan tali pusat dipermudah karena terpapar udara. Menurut Cunningham et.al (2006) air dari jeli wharton akan menghilang yang menyebabkan tali pusat mengalami mumifikasi dan perubahan morfologi sehingga terjadilah pelepasan tali pusat dari umbilikus.

Alasan mengapa tali pusat dianjurkan terbuka agar terkena udara secara leluasa ialah luka terbuka akan lebih cepat kering, disamping itu luka yang diberikan zat alami (kolostrum) akan lebih cepat mengering dibandingkan dengan dibiarkan terbuka. Karena pada dasarnya perawatan tali pusat haruslah bersih, steril, alami, terjaga kelembabannya, kering, dan sesuai dengan metode perawatan tali pusat sehingga mencegah terjadinya infeksi tali pusat. Selain itu, perawatan tali pusat dengan kolostrum lebih menghindari adanya infeksi tali pusat karena adanya zat anti inflamasi dan anti bakteri sehingga bagian tali pusat yang dioleskan kolostrum akan lebih terlindungi dari kuman.

Metode perawatan tali pusat metode kolostrum dan metode terbuka memiliki prinsip yang sama yaitu tidak ditutup dengan apapun atau dibiarkan terbuka, tetapi ternyata terdapat perbedaan antara perawatan kolostrum dan perawatan terbuka. Hasil Penelitian Allam, dkk
(2015), menunjukkan bahwa terdapat $80 \%$ dari kelompok eksperimen dengan lama pelepasan tali pusat rata - rata pada hari ke 4 dan hari ke 5 dan hanya $20 \%$ dari kelompok kontrol pada hari ke 5 dan hari ke 6. Sedangkan, pada kelompok kontrol hanya ada 11 bayi (3\%) yang "puput" pada hari ke 5 dan 75\% lebih dari 7 hari (Wihono PA, 2010); (Allam , NA. et.al. 2015). Tenaga kesehatan dan ibu-ibu perlu mengetahui bahwa metode kolostrum juga dapat digunakan untuk mempercepat proses pelepasan tali pusat pada bayi baru lahir. Pentingnya menerapkan perawatan tali pusat dengan metode kolostrum pada bayi baru lahir dapat mempercepat pemisahan tali pusat. Selain itu mengurangi infeksi dan membantu menghemat lebih banyak uang karena infeksi akan menghabiskan banyak uang untuk perawatan (Yulanda, NA \& Andikawati, 2015).

\section{Simpulan}

Pelepasan tali pusat menggunakan kolostrum sebagai terapi topikal lebih cepat dibandingkan metode terbuka. Metode kolustrum merupakan metode yang cocok, aman dan tidak mahal untuk manajemen tali pusat pada bayi baru lahir.

\section{Referensi}

Amrullah.(2015). Faktor Yang Mempengaruhi Proses Penyembuhan Luka. Jakarta: Buku Kesehatan

Aprilia. (2014).Teknik Perawatan Tali Pusat pada BBL. Jakarta

Aghamohammadi A, et al. (2012). Comparing the Effect of Topical Application of Human Milk and Dry Cord Care on Umbilical Cord Separation Time in Healthy Newborn Infants. Iranian Journal Of Pediatrics. 22(2):158-62.

Cunningham et al. (2006). Struktur Tali Pusat pada BBL. Jurnal Kesehatan

Dewi dkk. (2011). Asuhan Kebidanan Pada Ibu Nifas. Jakarta: Erlangga

Dinas Kesehatan Propinsi Jawa Barat. (2017). Profil Dinas Kesehatan Propinsi Jawa Barat

Dinas Kesehatan Kabupaten. Majalengka. (2017). Profil Kesehatan Kabupaten Majalengka Tahun 2016.

Elsobky FAA,. et.al. (2017). Effect of Topical Application of Mother Milk on Umbilical Cord Stump Separation Time Compared To Ethanol in Healthy Newborn. International Journal Novel Research in Healthcare and Nursing [Internet].4(1):1-11. Available from: 
www.noveltyjournal.com

Fita Supriyani dan Sri Handayani. (2011). Perbedaan Perawatan Tali Pusat Dengan Menggunakan ASI Dan Kassa Kering Terhadap Lama Pelepasan Tali Pusat Bayi Baru Lahir di BPS Endang Purwanti. Jurnal Kesehatan Samodra Ilmu.

IDAI. (2013). Air Susu Ibu dan KekebalanTubuh. Indonesian Pediatric Society. Retrived from http://www.idai.or.id

Ika Sofiana dan Ely Eko Agustina. 2013. Efektivitas Metode Kolostrum dan Metode Kasa Kering Terhadap Waktu Pelepasan Tali Pusat. Akademi Kebidanan YLPP Purwokerto.

JNPK. (2011). Kesehatan Reproduksi. Jakarta

Kementrian Kesehatan RI. (2017). Profil Kesehatan Indonesia Tahun 2016. Jakarta.

Lumsden. (2012). Perawatan Tali Pusat Dengan Metode Terbuka. Jurnal Kesehatan

Golshan M and Hossein N.(2013). Impact Of Ethanol, Dry Care And Human Milk On The Time For Umbilical Cord Separation. Journal Of Pakistan Medical Association. 2013;63: 1117

Allam NA, et al. (2015). The Effect Of Topical Application Of Mother Milk On Separation Of Umbilical Cord For Newborn Babies. American Journal Of Nursing Science. 4(5): 288-296.
Yulanda NA et al. (2015). Effectiveness Of Applying Breastfeeding/Milk On Umbilical Cord Tohasten Umbilical Cordremoval Compared To Ethanol And Dry Care Of Newborn: Literature Review. Nurse Faculty University Airlangga Surabaya.

Wihono PA. (2010). Gambaran Cara PerawAatan Tali Pusat dan Lama Waktu Pelepasan Tali Pusat di Wilayah Kerja Puskesmas Baki Sukoharjo. UMS Surakarta.

Pujar, Deepa, Francis. (2013). Breast Milk Application-An Emerging Trend To Reduce Timing Of Cord Separation (TCS) Among Newborn. IOSR Journal Nursing Health Science. 2013;1(4):39-42.

Ronald H. (2011). Pedoman dan Perawatan Balita. Bandung: Nuansa Aulia.

Vivian. (2008). Asuhan Kebidanan Ibu Nifas. Jakarta: Salemba Medika

WHO. (2015). Angka Kematian Bayi Baru Lahir. Withmore JM. (2010). Newborn Umbilical Cord Care: An Evidence Based Quality Improvement Project. University Of San Fransisco

WHO. (2010). Kesehatan Lingkungan Insani.WN. (2015). Gambaran Waktu Pelepasan Tali Pusat Antara Metode Kolostrum Dan Kasa Kering di Rumah Bersalin Bina Mulya Kab. Sumedang 